\title{
ANALISIS PENERAPAN STANDAR AKUNTANSI KEUANGAN TERHADAP PENYAJIAN LAPORAN KEUANGAN PADA CV. NURUL ABADI PALEMBANG
}

\author{
Oleh: Ande Sugama \\ (SMK MUHAMMADIYAH SEKAYU)
}

andesugama@gmail.com

\begin{abstract}
Abstrak-Metode yang digunakan dalam penelitian ini metode deskriptif kualitatif dengan cara pengumpulan data yaitu dokumentasi, wawancara dan studi literatur, adapun langkah-langkah untuk menganalisis data penelitian ini yaitu dengan cara reduksi data, penyajian data, penarikan kesimpulan. Hasil penelitian ini menunjukkan bahwa laporan keuangan yang disusun oleh perusahaan $C V$. Nurul Abadi Palembang belum sepenuhnya menerapkan standar akuntansi keuangan dan hal ini dikarenakan terbatasnya pengetahuan dan sumber daya manusia yang dimiliki. Laporan laba rugi, laporan perubahan modal, laporan neraca, laporan arus kas, catatan laporan keuangan, dan bukti transaksi yang dibuat oleh perusahaan masih menerapkan cara penyajian yang masih sederhana dan manual sesuai dengan kemampuan dan pengalaman pengurus keuangan perusahaan. Peneliti menyimpulkan perusahaan CV. Nurul Abadi Palembang selain belum menerapkan standar akuntansi keuangan dalam menyajikan laporan keuangan, juga memiliki berbagai kendala dalam penerapan laporan keuangan, diantaranya kendala sumber daya manusia yang belum menguasai dan memahami pengetahuan yang memadai tentang laporan keuangan yang sesuai standar.
\end{abstract}

Kata Kunci: Standar, Akuntansi Keuangan, Laporan Keuangan

\begin{abstract}
The method used in this study is descriptive qualitative method by collecting data, namely documentation, interviews and literature studies, as for the steps to analyze the data of this study, namely by reducing data, presenting data, drawing conclusions. The results of this study indicate that the financial statements compiled by the company CV. Nurul Abadi Palembang has not fully implemented financial accounting standards and this is due to the limited knowledge and human resources they have. Income statement, capital change report, balance sheet, cash flow statement, notes to financial statements, and proof of transactions made by the company still apply the simple and manual presentation method in accordance with the ability and experience of the company's financial management. The researcher concluded that the company $C V$. Besides Nurul Abadi Palembang has not applied financial accounting standards in presenting financial statements, it also has various obstacles in the implementation of financial statements, including constraints of human resources
\end{abstract}


that have not mastered and understand adequate knowledge of financial statements that are in accordance with standards.

\section{Keywords: Standards, Financial Accounting, Financial Reports}

\section{PENDAHULUAN}

Suatu kegiatan bisnis yang dijalankan oleh perusahaan, tentulah memiliki berbagai tujuan tersendiri, diantaranya adalah menginginkan keuntungan yang optimal atas usaha yang dijalankannya. Oleh karena itu, agar usaha yang dijalankan dapat dipantau perkembangannya, setiap perusahaan harus mampu membuat catatan, pembukuan, dan laporan terhadap semua kegiatan usahanya. Catatan keuangan selama periode tertentu dibuat dalam bentuk laporan keuangan.

Laporan keuangan yang dibuat haruslah sesuai dengan standar yang diterapkan di Indonesia, agar tujuan dari laporan tersebut sebagai penyedia informasi yang menyangkut posisi keuangan, kinerja, serta perubahan posisi keuangan suatu entitas bermanfaat bagi sejumlah besar pengguna dalam pengambilan keputusan ekonomi.

Laporan keuangan semakin baik penyusunannya akan berguna sebagai alat pertimbangan pihakpihak eksternal memberikan investasinya ke perusahaan tersebut. Manajemen keuangan memikul tanggung jawab utama dalam penyusunan dan penyajian laporan keuangan. Manajemen juga berkepentingan dengan informasi yang disajikan dalam laporan keuangan meskipun memiliki akses terhadap informasi manajemen dan keuangan tambahan yang membantu dalam melaksanakan tanggung jawab perencanaan, pengendalian, dan pengambilan keputusan. Laporan keuangan yang disusun untuk tujuan ini memenuhi kebutuhan bersama sebagian besar pengguna.

Pada mulanya laporan keuangan bagi suatu perusahaan hanyalah sebagai "alat penguji" dari pekerjaan bagian pembukuan, tetapi untuk selanjutnya laporan keuangan tidak hanya sebagai alat penguji saja tetapi juga sebagai dasar untuk dapat menentukan atau menilai posisi keuangan perusahaan tersebut, dimana dengan hasil analisa pihakpihak yang berkepentingan mengambil suatu keputusan. Jadi untuk mengetahui posisi keuangan suatu perusahaan serta hasil-hasil yang telah dicapai oleh perusahaan tersebut perlu adanya laporan keuangan dari perusahaan yang bersangkutan.

Menurut SAK 2015, Laporan keuangan yang lengkap biasanya meliputi neraca, laporan laba rugi, laporan perubahan posisi keuangan (yang dapat disajikan dalam berbagai cara, sebagai contoh, sebagai laporan arus kas atau laporan arus dana), catatan dan laporan lain serta materi penjelasan yang merupakan bagian 
integral dari laporan keuangan (IAI, 2014: 2).

Laporan keuangan adalah "Hasil dari proses akuntansi yang dapat digunakan sebagai alat untuk berkomunikasi antara data keuangan atau aktivitas suatu perusahaan dengan pihak-pihak yang berkepentingan dengan data atau aktivitas perusahaan tersebut" (Munawir, 2010: 2).

Pembuatan laporan keuangan dibuat sesuai dengan kaidah keuangan yang berlaku agar mampu menunjukkan kondisi dan posisi keuangan yang sesungguhnya. Laporan keuangan juga harus dibuat sesuai dengan aturan yang berlaku sehingga mudah untuk dibaca, dipahami dan dimengerti oleh berbagai pihak yang berkepentingan, terutama pihak pemilik usaha dan managemen (Kasmir, 2012: 4).

CV. Nurul Abadi adalah sebuah perusahaan yang bergerak dalam bidang pelayanan jasa aqiqah, catering dan qurban. Perusahaan ini mulai memiliki badan hukum sejak tahun 2014. Perusahaan ini beralamatkan jalan swadaya lorong persatuan 1 nomor 2918, Pakjo Palembang.

Perusahaan memiliki 3 orang karyawan dalam bidang administrasi dan keuangan serta 20 orang karyawan yang membantu pelayanan jasa yang sediakan. Laporan keuangan perusahaan yang disajikan atau dibuat selama beberapa tahun semenjak berlakunya badan hukum belum diterapkan secara standar akuntansi keuangan, perusahaan hanya menerapkan laporan keuangan bersifat intern yang sesuai dengan kemampuan pengelolah keuangan perusahaan. Berdasarkan observasi yang dilakukan peneliti diketahui bahwa pada CV. Nurul Abadi Palembang menerapkan laporan keuangan belum sesuai dengan standar yang ada.

"Analisis merupakan kemampuan merinci suatu kesatuan ke dalam bagian-bagian sehingga struktur keseluruhan dapat dipahami dengan baik" (Dimyati dan Mudijono, 2009:27). Sedangkan menurut Sudijono (2009:51) "Analisis adalah kemampuan seseorang merinci atau menguraikan suatu bahan atau keadaan menurut bagian-bagian atau faktor-faktor yang satu dengan faktor-faktor lainnya".

Berdasarkan uraian di atas, peneliti menyimpulkan analisis adalah kemampuan seseorang dalam menggali lebih banyak informasi yang terkandung di dalam suatu data.

Penerapan adalah suatu tindakan atau pelaksanaan dari sebuah rencana yang sudah disusun secara matang dan terperinci (elkawaqi.blogspot.com). Kamus Besar Bahasa Indonesia (KBBI, 2008:529), penerapan dalah perbuatan menerapkan atau pelaksanaan. Menurut beberapa ahli berpendapat bahwa, penerapan adalah suatu perbuatan mempraktekkan suatu 
teori, metode, dan hal lain untuk mencapai tujuan tertentu dan suatu kepentingan yang diinginkan oleh suatu kelompok atau golongan yang telah terencana dan tersusun sebelumnya (ejournal.unsrat.ac.id).

Berdasarkan pengertian di atas peneliti menyimpulkan penerapan merupakan sebuah tindakan yang mempraktekkan atau menerapkan apa yang sudah dirumuskan.

Standar Akuntansi keuangan (SAK) adalah pernyataan atau interprestasi yang diterbitkan oleh Dewan Standar Akuntansi Keuangan Ikatan Akuntan Indonesia dan Dewan Standar Akuntansi Syariah Ikatan Akuntan Indonesia serta peraturan regulator pasar modal untuk entitas yang berada di bawah pengawasannya (IAI, 2014: 1.3).

Menurut Fess (2006: 16) SAK adalah "Bagaimana perusahaan membuat laporan dan apa yang akan mereka laporkan, semua pihak berkepentingan akan memberikan perhatian pada pembuatan prinsipprinsip tersebut". Sedangkan menurut Manurung (2011:8) "SAK adalah standar yang diperlukan untuk menyeragamkan pelaporan keuangan perusahaan".

Berdasarkan uraian di atas, peneliti menyimpulkan SAK adalah prinsip atau petunjuk perusahaan dalam pembuatan dan penyajian laporan keuangan. "Laporan keuangan merupakan alat yang sangat penting untuk memperoleh informasi sehubungan dengan posisi keuangan dan hasil-hasil yang telah dicapai oleh perusahaan yang bersangkutan" (Munawir dalam Fahmi, 2011:2). Sedangkan menurut Kasmir (2012:7) "Laporan keuangan adalah laporan yang menunjukkan kondisi keuangan perusahaan pada saat ini atau dalam suatu periode tertentu".

Berdasarkan uraian di atas, peneliti menyimpulkan laporan keuangan merupakan suatu informasi yang menggambarkan kondisi atau posisi keuangan suatu perusahaan, dan lebih jauh informasi tersebut dapat digunakan sebagai gambaran kinerja keuangan perusahaan tersebut.

\section{METODE PENELITIAN}

Metode penelitian yang diambil adalah metode deskriptif kualitatif, metode ini adalah metode yang mengambil keadaan sesungguhnya dari fenomena yang sebelumnya.

Untuk mencari data dan keterangan yang diperlukan digunakan teknik sebagai berikut: (1) Dokumentasi, menurut Sugiyono (2013: 422) dokumentasi adalah “ pengumpulan data dengan mempelajari dan meyakinkan dokumen-dokumen yang terkait dengan penelitian". Sedangkan menurut Arikunto (2010:274) "dokumentasi adalah mencari data, mengenai hal-hal atau variabel yang berupa catatan, transkrip, buku, surat kabar, majalah, prasasti, notulen 
rapat, lengger, agenda, dan sebagainya". Teknik ini digunakan untuk mengetahui laporan neraca, laba rugi, perubahan modal dan arus kas, catatan-catatan keuangan, buktibukti transaksi, dan sebagainya (2) Wawancara, menurut Sugiyono (2013:410) “ wawancara merupakan penentuan dua orang untuk bertukar informasi dan ide melalui tanya jawab sehingga dapat dikontruksikan suatu topik tertentu". Wawancara dilakukan untuk mengumpulkan informasi atau data yang berhubungan dengan keadaan umum perusahaan seperti latar belakang pendirian, struktur, pembagian tugas dan tanggung jawab kerja perusahaan, laporan akhir tahun serta hal lainnya.
HASIL PENELITIAN

Catatan keuangan merupakan kondisi keuangan perusahaan yang menggambarkan laporan keuangan yang dibuat oleh perusahaan. Laporan keuangan mencerminkan kelangsungan kinerja suatu perusahaan kedepannya. Melalui laporan keuangan, para pengguna laporan keuangan mengetahui kondisi keuangan suatu perusahaan dan dapat memprediksi apakah perusahaan tersebut akan bertahan ke depannya.

Pada tahun 2014 perusahaan pernah membuat laporan akhir yang dinamai laporan bulanan CV. Nurul Abadi Palembang. Untuk lebih jelas dapat dilihat di bawah ini:

\section{GAMBAR LAPORAN KEUANGAN CV. NURUL ABADI PALEMBANG}
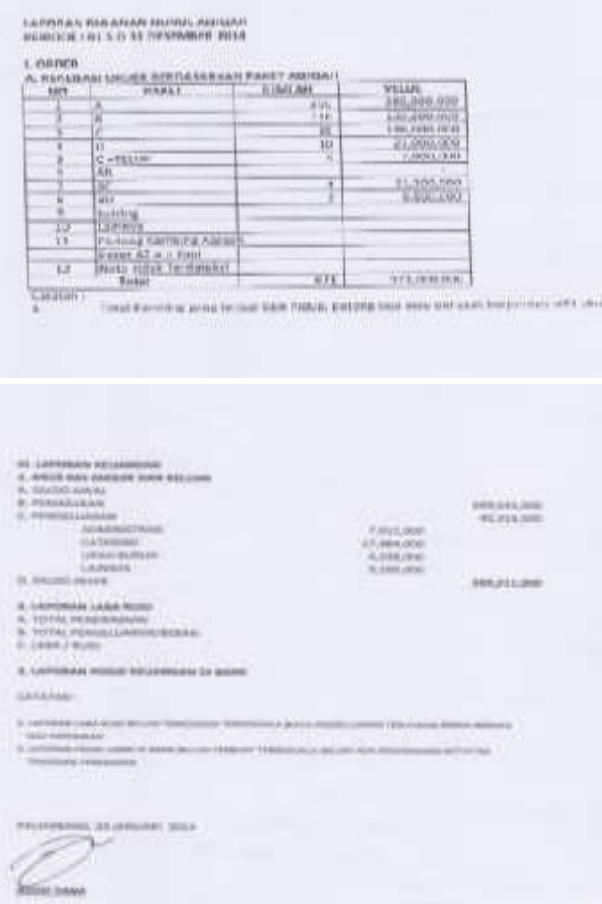

Sumber: CV. Nurul Abadi Palembang, 2014 
Tabel 1. Buku Kas CV. Nurul Abadi Palembang Periode Desember 2015

(Rp)

\begin{tabular}{|c|c|c|c|c|c|}
\hline Tangal & Keterangan & Ref & Debit & Kredit & Saldo \\
\hline \multirow[t]{12}{*}{1 Des } & Paket E4 Via Abdussomad & & - & 8.300 .000 & 8.300 .000 \\
\hline & Obat Kambing & & 40.000 & - & 8.260 .000 \\
\hline & Ojek Eli & & 50.000 & - & 8.210 .000 \\
\hline & Bayar Kemplang & & 500.000 & - & 7.710 .000 \\
\hline & Bensin Kijang & & 100.000 & - & 7.610 .000 \\
\hline & Bensin Inova & & 150.000 & - & 7.460 .000 \\
\hline & Pak Rozi & & 50.000 & - & 7.410 .000 \\
\hline & Kasbon Pak Yar & & 100.000 & - & 7.310 .000 \\
\hline & Bensin Scoopy & & 20.000 & - & 7.290 .000 \\
\hline & Kopi+Gula & & 30.000 & - & 7.260 .000 \\
\hline & Gaji Orang Kandang & & 105.000 & - & 7.155 .000 \\
\hline & Bensin Mingguan Hendra & & 50.000 & - & 7.105 .000 \\
\hline \multirow[t]{22}{*}{2 Des } & Uang Kas & & - & 350.000 & 7.455 .000 \\
\hline & Paket A2 M. Hilman & & - & 2.000 .000 & 9.455 .000 \\
\hline & Pelunasan $8 \mathrm{Kg} \mathrm{N}$. Minyak & & - & 400.000 & 9.855 .000 \\
\hline & Paket D1 Ratifa & & - & 1.900 .000 & 11.755 .000 \\
\hline & Paket A2 Maulana & & - & 2.200 .000 & 13.955 .000 \\
\hline & Paket A2 Saif / Via Lilik & & - & 2.200 .000 & 16.155 .000 \\
\hline & Paket A2 Bayu \& M. Fadhil & & - & 2.600 .000 & 18.755 .000 \\
\hline & Bensin Carry & & 150.000 & - & 18.605 .000 \\
\hline & Bensin Genset & & 50.000 & - & 18.655 .000 \\
\hline & Beli Sagu+Saos & & 67.500 & - & 18.722 .500 \\
\hline & Fotokopi & & 3.000 & - & 18.725 .500 \\
\hline & Beli Saos & & $18, .000$ & - & 18.743 .500 \\
\hline & Makanan Burung & & 10.000 & - & 18.753 .500 \\
\hline & Diambil Arina & & 50.000 & - & 18.803 .500 \\
\hline & Gaji Drh. Budi & & 2.000 .000 & - & 20.803 .500 \\
\hline & Fee Kk Lilik & & 400.000 & - & 21.203 .500 \\
\hline & Gaji Orang Kandang & & 90.000 & - & 21.293 .500 \\
\hline & Bayar Warung Abi & & 5.000 .000 & - & 26.293 .500 \\
\hline & Kasbon Imam & & 50.000 & - & 26.343 .500 \\
\hline & Pulsa Kantor & & $2, .000$ & - & 26.365 .500 \\
\hline & Bayar Kangen Water & & 50.000 & - & 26.415 .500 \\
\hline & Ojek Wak Udin & & 85.000 & - & 26.500 .500 \\
\hline \multirow[t]{17}{*}{3 Des } & Uang Kas & & - & 300.000 & 26.800 .500 \\
\hline & Paket C1 Hj. Faizah & & - & 1.700 .000 & 28.500 .500 \\
\hline & Paket C2 M. Kafie & & - & 3.400 .000 & 31.900 .500 \\
\hline & Paket A1 Saqilla & & - & 1.200 .000 & 33.100 .500 \\
\hline & Paket A1 Khanaya & & - & 1.100 .000 & 34.200 .500 \\
\hline & Paket B1 Hermawan & & - & 1.200 .000 & 35.400 .500 \\
\hline & Paket A2 Muhammad Farid & & - & 2.600 .000 & 38.000 .500 \\
\hline & Pisang + Ojek & & 70.000 & - & 37.930 .500 \\
\hline & Beli Snack + Tempe & & 39.000 & - & 37.891 .500 \\
\hline & Ojek Kk Eli & & 30.000 & - & 37.861 .500 \\
\hline & Tambahan Uang Bumbu & & 50.000 & - & 37.811 .500 \\
\hline & Diambil Bapak & & 50.000 & - & 37.761 .500 \\
\hline & Bensin Kijang & & 150.000 & - & 37.611 .500 \\
\hline & Bensin Scoopy & & 10.000 & - & 37.601 .500 \\
\hline & Gaji Pak Yar & & 1.400 .000 & - & 36.201 .500 \\
\hline & Gaji Wak Udin & & 1.500 .000 & - & 34.701 .500 \\
\hline & Gaji Orang Kandang & & 90.000 & - & 34.611 .500 \\
\hline
\end{tabular}

(Sumber: CV. Nurul Abadi Palembang,2015) 
Perbandingan antara Laporan Keuangan Berdasarkan PSAK dengan Laporan Keuangan CV. Nurul Abadi Palembang

Laporan keuangan perusahaan sendiri didefinisikan sebagai kumpulan laporan yang menyajikan informasi mengenai aktivitas keuangan perusahaan.
Laporan keuangan tersebut disajikan beberapa informasi ialah laporan laba rugi, laporan perubahan ekuitas, laporan neraca, laporan arus kas. Perbandingan laporan keuangan yang dimaksudkan dalam penelitian ini adalah bagian penting dari temuan penelitian.

Tabel 2. Perbandingan Laporan Keuangan

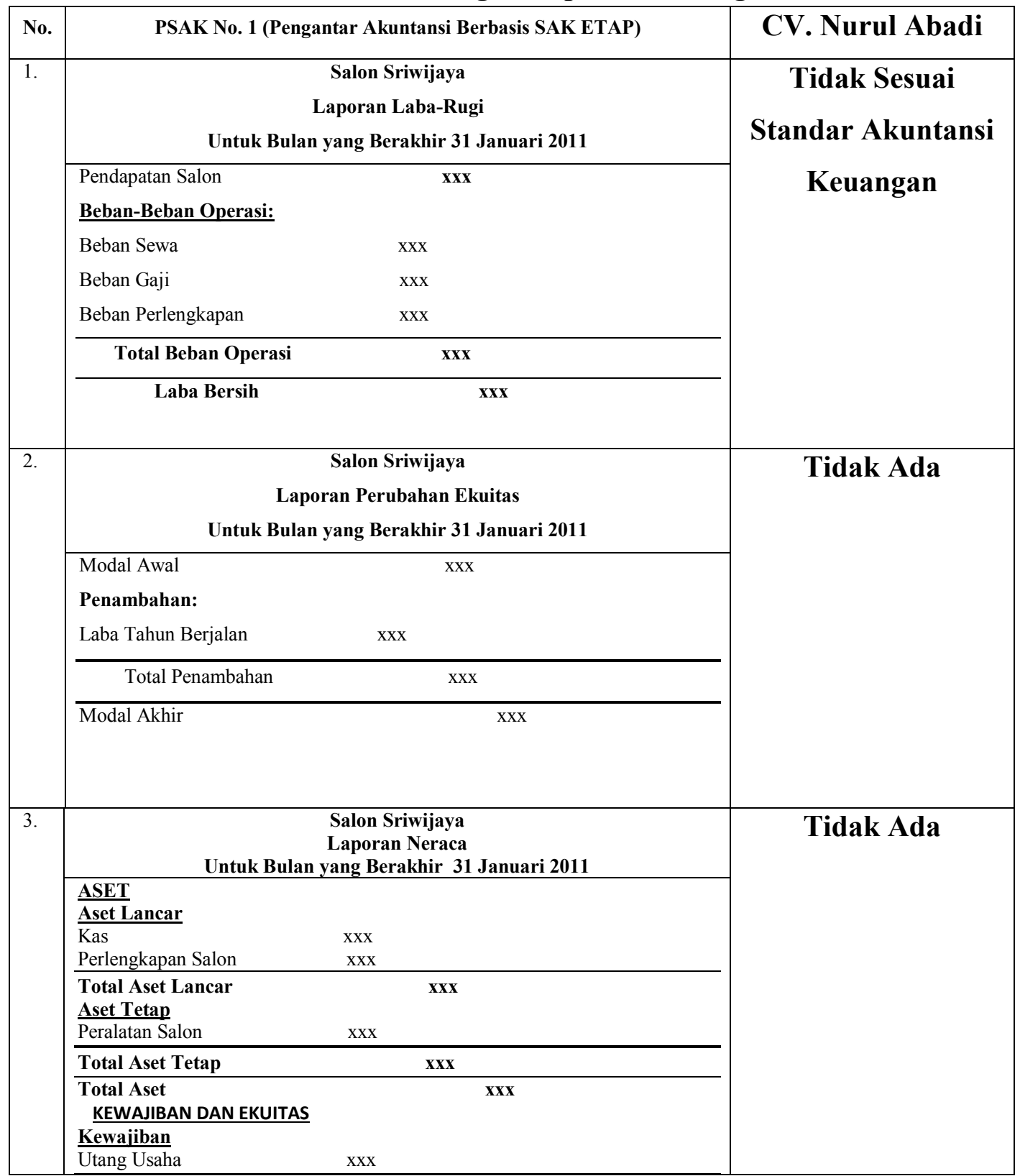




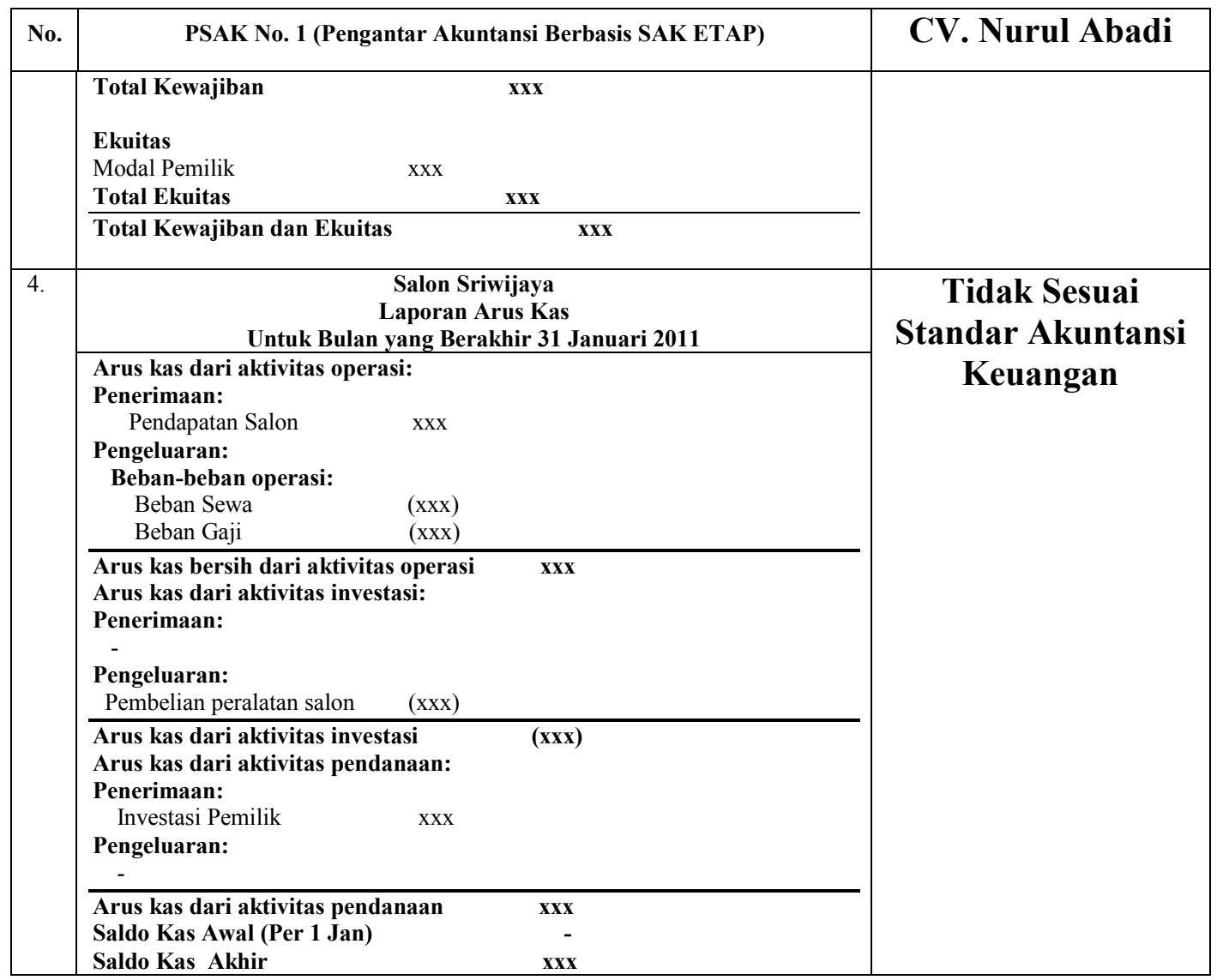

Pada prinsipnya CV. Nurul Abadi Palembang telah membuat catatan keuangan perusahaan. Akan tetapi, catatan tersebut belum sesuai dengan yang seharusnya. Untuk lebih jelas mengenai perbandingan laporan keuangan yang dibuat oleh CV. Nurul Abadi Palembang dengan standar yang ada yaitu PSAK No. 1 (Pengantar Akuntansi Berbasis SAK ETAP) dilihat pada table berikut:

\subsection{Pembahasan}

Pembuatan laporan keuangan perusahaan merupakan hal yang wajib dilakukan oleh mereka yang bergerak dalam dunia usaha. Semua usaha yang dikelola dengan baik, harus memiliki sebuah catatan yang berisi informasi mengenai semua aktivitas keuangan.

Bukan hanya perusahaan yang sudah berskala besar yang memiliki kewajiban untuk membuat laporan keuangan perusahaan. Sebab, perusahaan kecil sekalipun sebenarnya dianjurkan untuk membuat laporan keuangan perusahaan.

Laporan keuangan bagi pihak intern perusahaan akan memberikan manfaat dalam rangka pengambilan keputusan dan kebijakan yang relevan. Sementara, untuk tujuan keluar perusahaan dimaksudkan bagi pihak luar yang memiliki kepentingan serta hak untuk mendapatkan laporan keuangan 
tersebut. Pihak luar tersebut antara lain pemegang saham, pemilik perusahaan, kreditur, bank atau masyarakat umum. Tujuan laporan keuangan adalah memberikan informasi lainnya yang bermanfaat bagi pengguna laporan dalam rangka membuat keputusan ekonomi serta menunjukkan pertanggungjawaban managemen atas penggunaan sumber daya yang dipercayakan kepadanya. Laporan keuangan menunjukkan kinerja keuangan perusahaan pada tahun berjalan sebagai bahan evaluasi kinerja keuangan perusahaan tahun berikutnya.

Setelah dilakukan analisisanalisis terhadap laporan keuangan CV. Nurul Abadi Palembang, selanjutnya peneliti membahas kemampuan perusahaan dalam membuat laporan keuangan. Analisis yang sudah dilakukan, diantaranya 1) laporan laba rugi 2) laporan perubahan ekuitas 3) laporan neraca 4) laporan arus kas.

Analisis laporan keuangan periode 2014 CV. Nurul Abadi Palembang, yaitu perusahaan belum membuat laporan akhir untuk keperluan pihak ekstern, catatan keuangan yang dimiliki perusahaan hanya berupa buku kas dan didampingi oleh bukti transaksi invoice yang digunakan untuk semua transaksi penjualan tunai dan kredit, penggunaan nama akun belum sesuai dengan standar akuntansi keuangan. Namun, pada tahun 2014 perusahaan sudah membuat laporan keuangan dan laporan bulanan yang sesuai dengan kemampuan dan pengalaman pengelolah keuangan yang dibuat secara sederhana dan manual. Laporan arus kas yang dibuat perusahaan hanyalah laporan dari arus kas operasional perusahaan. Laporan laba rugi yang dibuat juga tidak sesuai dengan standar akuntansi keuangan. Dalam laporan akhir yang dibuat pada tahun 2014, perusahaan tidak memenuhi syarat standar akuntansi keuangan yaitu dalam laporan laba rugi tidak terdapat kop laporan (nama perusahaan, jenis laporan dan periode yang dibuat), pengeluaran dan penerimaan tidak terdapat nominal sehingga perusahaan tidak mengetahui laba atau rugi di dalam perusahaan, untuk laporan arus kas yang dibuat pun terdapat banyak kesalahan yaitu perusahaan belum memahami makna laporan arus kas itu sendiri, laporan arus kas adalah laporan yang memberikan informasi arus kas perusahaan sebagai dasar menilai kemampuan perusahaan dalam menghasilkan dan menggunakan kas. Adapun komponen dalam laporan arus kas yaitu kas (kas perusahaan dan rekening giro bank), setara kas (investasi yang sifatnya sangat likuid yang segera dapat dijadikan kas), aktivitas operasi, aktivitas investasi, dan aktivitas pendanaan. Sedangkan yang terdapat dalam laporan arus kas hanyalah kas dan aktivitas operasional, dan tidak terdapat kop 
laporan. Laporan posisi keuangan di Bank (dibutuhkan rekonsiliasi jika ingin membuat laporan posisi keuangan di bank, yang dianjurkan adalah membuat laporan perubahan modal untuk mempermudah dalam proses pembuatan laporan akhir keuangan), laporan neraca tidak dibuat. Laporan order adalah laporan tambahan yang dibuat oleh perusahaan untuk melihat jumlah seluruh orderan perusahaan dalam masa periode yang dibuat. Namun kesalahan dalam pembuatan laporan order adalah belum dispesifikasikan secara baik setiap paket dan orderan penjualan yang dibuat.

Periode 2015 maupun periode sebelumnya, CV. Nurul Abadi Palembang melakukan pencatatan transaksi keuangan dengan cara satu buku catatan. Oleh karena itu, keuangan perusahaan tidak dapat dianalisis dengan jelas pada tiap-tiap periode akuntansi. Temuan lain, peneliti menyatakan bahwa pelaporan keuangan perusahaan sangat tidak sesuai dengan sistem pelaporan keuangan yang telah diatur dalam PSAK. Kendala dari perusahaan CV. Nurul Abadi Palembang menerapkan SAK ETAP dalam proses penyusunan laporan keuangan adalah sebagai berikut:

a. Sumber daya manusia yang dimiliki CV. Nurul Abadi Palembang kurang memiliki pengetahuan yang memadai tentang laporan keuangan yang sesuai standar. b. Petugas bagian administrasi keuangan harus merangkap pekerjaan bagian operasional lain di kantor perusahaan.

c. Kurangnya pemahaman managemen perusahaan akan pentingnya laporan keuangan yang lengkap dan sesuai standar. Tahap pelaporan yang sesuai dengan standar akuntansi keuangan (Berbasis SAK ETAP) adalah:

A) Siklus akuntansi, siklus akuntansi adalah prosedur akuntansi yang biasanya digunakan oleh perusahaan untuk mencatat transaksi dan membuat laporan keuangan. Satu siklus akuntansi terdiri dari banyak fungsi yang dilakukan dalam rangka mengolah transaksi menjadi informasi keuangan. Langkah-langkah dalm siklus akuntansi yaitu :

1. Tahap Pencatatan, dalam tahap ini terdapat transaksi internal maupun eksternal, mengumpulkan dan menganalisis bukti transaksi, perjurnalan umum atau khusus, dan pemostingan atau pemindahanbukuan ke buku besar.

2. Tahap Pengikhtisaran, pada tahap ini menyusun neraca saldo yang akunakunnya terdapat dalam buku besar, melakukan 
data-data yang perlu disesuaikan dan membuat neraca saldo disesuaikan.

3. Tahap Pelaporan Keuangan, berisi penyusunan laporan keuangan (laporan laba rugi, laporan perubahan modal, laporan neraca, laporan arus kas), menyusun jurnal penutup dan neraca saldo setelah penutupan.

Hasil penelitian yang dilakukan, mengindikasikan bahwa CV. Nurul Abadi Palembang belum memenuhi standar akuntansi keuangan. Oleh karena itu, peneliti berpendapat bahwa CV. Nurul Abadi Palembang harus memperbaiki sistem pelaporan yang ada agar keuangan perusahaan dapat dianalisis dan dijadikan sebagai landasan dalam penentuan kebijakan yang menguntungkan perusahaan.

\section{KESIMPULAN DAN SARAN Kesimpulan}

Berdasarkan hasil penelitian tentang penerapan standar akuntansi keuangan tentang penyajian laporan keuangan pada CV.Nurul Abadi Palembang maka peneliti dapat mengambil kesimpulan sebagai berikut:

1) Laporan keuangan yang disusun oleh perusahaan CV. Nurul Abadi Palembang adalah laporan kas kecil harian, laporan laba rugi, laporan realisasi order, laporan perubahan kas di bank dan bukti transaksi harian. CV. Nurul Abadi Palembang belum menyajikan laporan keuangan yang sesuai dengan SAK ETAP.

2) Penyusunan dan penyajian laporan keuangan berdasarkan SAK ETAP dimulai dari mengumpulkan bukti transaksi, menganalisis transaksi, mencatat transaksi dalam bentuk jurnal, memposting ke buku besar, membuat neraca saldo, membuat ayat jurnal penyesuaian, menyusun neraca saldo setelah disesuaikan, kemudian membuat laporan keuangan yang dimulai dari laporan laba rugi, laporan perubahan ekuitas, neraca, laporan arus kas, dan catatan atas laporan keuangan.

3) Kendala dari perusahaan CV. Nurul Abadi Palembang menerapkan SAK ETAP dalam proses penyusunan laporan keuangan adalah sebagai berikut:

a. Sumber daya manusia yang dimiliki CV. Nurul Abadi Palembang kurang memiliki pengetahuan yang memadai tentang laporan keuangan yang sesuai standar.

b. Petugas bagian administrasi keuangan harus merangkap pekerjaan bagian operasional lain di kantor perusahaan.

c. Kurangnya pemahaman managemen perusahaan akan pentingnya laporan keuangan 
yang lengkap dan sesuai standar.

\section{Saran}

Berdasarkan penelitian yang telah dilakukan, berikut ini adalah saran atau rekomendasi yang diberikan oleh peneliti:

1) Bagi Perusahaan CV. Nurul Abadi Palembang

a. Perusahaan sebaiknya memperkerjakan karyawan di bidang akuntansi yang memadai agar penyusunan laporan keuangan sesuai standar akuntansi keuangan yang ada dan tidak ada karyawan yang melakukan pekerjaan rangkap.

b. Perusahaan sebaiknya meningkatkan kesadaran akan pentingnya laporan keuangan bagi penilaian kinerja mereka.

2) Bagi Universitas PGRI Palembang

Bagi Civitas Akademika Perguruan Tinggi dapat dijadikan bahan kepustakaan dan informasi bagi pihak-pihak yang mempunyai kepentingan terutama penelitian sejenis.

3) Bagi Peneliti Lain

Dapat dijadikan bahan referensi dan rujukan dalam penelitian di masa mendatang.

\section{DAFTAR PUSTAKA}

Arikunto,Suharsimi. 2010. Prosedur Penelitian. Yogyakarta: Rineka Cipta.
Departemen Pendidikan Nasional. 2008. Kamus Besar Bahasa Indonesia. Jakarta: Gramedia Pustaka Umum.

Dimyati\&Mudijono. 2009. Belajar dan Pembelajaran. Jakarta: Rineka Cipta.

Fahmi, Irham. 2011. Analisis Laporan Keuangan. Bandung: Alfabeta.

Fess. 2006. Accounting Pengantar Akuntansi. Jakarta: Salemba Empat

Harahap, Sofyan Syafri. 2010. Analisis Kritis Atas Laporan Keuangan. Jakarta: PT.Raja Grafindo Persada.

Ikatan Akuntansi Indonesia. 2014. Standar Akuntansi Keuangan. Jakarta: IAI

Standar Akuntasi Keuangan

Entitas Tanpa Akuntabilitas Publik. Jakarta: IAI

.2012

Pengantar Akuntansi (berbasis SAK ETAP). Sumsel: IAI

Kasmir. 2012. Analisis Laporan Keuangan edisi 5. Jakarta: PT.Raja Grafindo Persada.

Manurung. 2011. Akuntansi Dasar. Jakarta: Erlangga

Munawir, S. 2010. Analisa Laporan Keuangan.Yogyakarta: Liberty

Sugiyono. 2013. Metode Penelitian Bisnis. Bandung: Alfabeta.

Sujiyono, Anas. 2009. Pengantar Statistik Pendidikan. Jakarta: PT.Raja Grafindo Persada

Tim,Penyusun. 2015. Pedoman Penulisan Skripsi. Palembang: FKIP Universitas PGRI Palembang.

Umar, Husein.2012. Metode Penelitian. Jakarta: Salemba Empat. 
http://el-

kawaqi.blogspot.com/2012/12/

pengertian-implementasi-

menurut-para.html. diakses tanggal 16 Januari 2016.

http://ejournal.unsrat.ac.id/index.php /politico/article/view/2581.

diakses tanggal 16 Januari 2016. 